\title{
MANAJEMEN PASOKAN DAN PENGADAAN ELEKTRONIK: MENCIPTAKAN NILAI TAMBAH DALAM RANTAI PASOKAN
}

\author{
Joko Triono \\ Univeritas $M H$. Thamrin \\ Email: treeono82@gmail.com
}

\begin{abstract}
Abstrak
Meningkatnya perhatian pada manajemen rantai pasokan menciptakan fokus yang lebih besar pada tautan manajemen pasokan dalam rantai pasokan. Fokus ini akan menjadi lebih intens ketika perusahaan terus mengadopsi strategi pengadaan elektronik untuk meningkatkan keunggulan kompetitif Internet. Manajer pasokan perlu memahami dampak teknologi dan mendapatkan kompetensi dalam membuat kasus bisnis untuk pengadaan elektronik, implikasinya sangat dalam bagi pemasar industri.
\end{abstract}

Kata Kunci: Manajemen Rantai Pasokan, Pengadaan Elektronik, Nilai Tambah Ekonomis.

\begin{abstract}
Increased attention to supply chain management creates a greater focus on supply management links in the supply chain. This focus will become more intense as companies continue to adopt electronic procurement strategies to increase the competitive advantage of the Internet. Supply managers need to understand the impact of technology and gain competence in making business cases for electronic procurement, the implication is very deep for industrial marketers.
\end{abstract}

Keywords: Supply Chain Management, Electronic Procurement, Economic Value Added.

\section{A. PENDAHULUAN}

Manajemen rantai pasokan atau Supply Chain Management (SCN) telah booming di dunia bisnis sebagai salah satu perhatian utama manajemen perusahaan selama dekade terakhir. Alasannya jelas, $70 \%$ dari pendapatan penjualan perusahaan, rata-rata, dihabiskan untuk kegiatan yang terkait dengan rantai pasokan dari pembelian material hingga distribusi dan layanan produk jadi ke pelanggan akhir.

Ketika ekonomi dunia menjadi semakin kompetitif, mempertahankan daya saing dan profitabilitas yang dihasilkan kurang tergantung pada kemampuan untuk menaikkan harga Sebaliknya, perusahaan perlu bersaing berdasarkan inovasi produk, kualitas yang lebih tinggi, dan waktu respons yang lebih cepat, yang semuanya harus disampaikan, dalam banyak kasus secara bersamaan dan selalu dengan biaya terendah yang dapat dicapai. Dimensi kompetitif tersebut tidak dapat diberikan tanpa rantai pasokan yang dikelola secara efektif. Perusahaan 
dengan rantai pasokan paling kompetitif adalah dan akan terus menjadi pemenang besar dalam bisnis kontemporer.

Rantai Pasokan adalah rantai mencakup semua kegiatan yang berhubungan dengan aliran dan transformasi barang dari tahap bahan baku sampai ke pengguna akhir, serta arus informasi yang terkait. Manajemen Rantai Pasokan adalah integrasi kegiatan-kegiatan ini melalui peningkatan hubungan rantai pasokan untuk mencapai keunggulan kompetitif yang berkelanjutan (Handfield \& Nichols Jr., 1999).

Definisi tersebut menunjukkan bahwa semua tautan dalam rantai pasokan harus kuat dan terintegrasi dengan baik. Namun, diperdebatkan di sini bahwa tautan utama, yang menetapkan fondasi untuk yang lain, adalah manajemen persediaan pada ujung input rantai (Dobler \& Burt, 1996). Hal ini merupakan tautan dalam rantai pasokan yang berfungsi sebagai aktivitas batas jangkauan pada ujung input bisnis di mana basis pemasok dibangun berdasarkan pada kemampuan pemasok untuk membantu perusahaan mencapai dimensi kompetitif. Di sinilah para pemasar industri berhadapan langsung dengan tuntutan rantai pasokan perusahaan pembeli.

Meningkatnya dorongan pada manajemen rantai pasokan telah mempertajam fokus manajemen puncak pada potensi nilai tambah dari manajemen persediaan. Sebuah survei baru-baru ini menunjukkan bahwa 76\% CEO mengharapkan manajemen pasokan berkontribusi pada nilai pemegang saham karena perusahaan terus bergerak menuju lebih banyak outsourcing (Nelson et al., 2002). Dampak potensial terhadap daya saing dan profitabilitas sangat besar karena rata-rata perusahaan pabrikan menghabiskan sekitar 50\% dari pendapatan penjualannya untuk pembelian barang dan jasa yang dibutuhkan untuk menghasilkan produk akhir.Itu adalah di ujung pasokan dari rantai pasokan di mana sebagian besar pengeluaran untuk kegiatan rantai pasokan ada.

Penekanan yang meningkat pada manajemen pasokan, bukan pada "pembelian" yang lebih tradisional, mengharuskan manajer pemasok profesional bergerak melampaui fokus transaksi khusus yang dilakukan di mana harga dan ketersediaan adalah faktor kunci yang harus dipertimbangkan dalam keputusan pembelian. Dasar-dasar baru dari manajemen persediaan mensyaratkan agar manajer persediaan mengambil pandangan yang lebih strategis tentang apa yang mereka lakukan. Dasar-dasar baru tersebut mencakup pemahaman komprehensif tentang penetapan target biaya, rekayasa nilai, pengembangan pemasok, dan pengadaan listrik elektronik (Nelson et al., 2002). Tiga yang pertama tidak benar-benar baru, telah ada sebagai bagian implisit dari manajemen persediaan untuk beberapa waktu. Lebih 
akurat untuk mengatakan bahwa mereka ditutupi oleh redis. Ini adalah pengadaan elektronik, penggunaan Internet yang produktif untuk meningkatkan efektivitas dan efisiensi rantai pasokan, yang baru.

Manajemen pasokan strategis memiliki potensi untuk penciptaan nilai yang signifikan bagi perusahaan. Para profesional bisnis yang telah lama terlibat dalam manajemen persediaan memahami kekuatannya untuk menciptakan nilai. Munculnya pengadaan elektronik dalam beberapa tahun terakhir adalah menciptakan profil yang lebih tinggi untuk manajemen pasokan, meningkatkan visibilitasnya ke manajemen puncak.

Tantangan bagi mereka yang beroperasi di ujung pasokan dari rantai pasokan adalah membuat kasus bisnis yang meyakinkan untuk apa yang mereka lakukan. Meskipun CEO mengharapkan manajemen persediaan untuk berkontribusi pada nilai pemegang saham, manajer persediaan yang efektif perlu merasa nyaman dengan bahasa manajemen puncak untuk mengomunikasikan bagaimana nilai itu dibuat. Perpindahan ke pengadaan elektronik menyediakan peluang unik bagi manajer persediaan karena dua alasan. Pertama, penerapan teknologi untuk meningkatkan daya saing dan profitabilitas menjadi agenda setiap CEO yang berpikiran maju. Kedua, penerapan teknologi untuk memasok manajemen, di mana perusahaan menghabiskan sebagian besar uang operasi, memfokuskan lebih banyak perhatian manajemen puncak pada masalah itu. Sebuah studi baru-baru ini oleh Deloitte Consulting dari 200 perusahaan global menunjukkan bahwa 30\% telah mulai menerapkan setidaknya solusi pengadaan elektronik dasar sedangkan 61\% sedang merencanakan atau sedang mempertimbangkan implementasi (Whyte, 2000).

Membuat kasus bisnis untuk pengadaan elektronik mensyaratkan bahwa manajer persediaan memahami konsep nilai tambah ekonomis atau Economic Value Added (EVA), yang dianggap sebagai ukuran keuangan komprehensif penciptaan nilai. Selain menggunakan EVA untuk meyakinkan manajemen puncak tentang kemanjuran strategi pengadaan elektronik, manajer persediaan dapat memberikan kontribusi penting pada unsur yang hilang dalam keseluruhan gerakan manajemen rantai pasokan metode untuk mengukur total nilai ekonomi di seluruh rantai pasokan (Nelson et al., 2002).

Artikel ini dimulai dengan ikhtisar proses pembelian. Definisi pengadaan elektronik ditawarkan dan perannya dalam proses pembelian dijelaskan. Beberapa pendekatan untuk pengadaan elektronik disertakan dan manfaat dari strategi pengadaan elektronik diidentifikasi. Diskusi kemudian beralih ke bagaimana pengadaan elektronik dapat memiliki 
efek positif pada EVA. Artikel ini diakhiri dengan diskusi tentang implikasi bagi pemasar industri.

Ketika pembelian tradisional berevolusi menjadi manajemen pasokan yang lebih komprehensif, penting bagi pemasar industry pemasok dan pemasok potensial pembeli industri memahami tuntutan baru tentang manajemen pasokan. Pemasok yang dapat membantu manajer persediaan membuat kasus bisnis untuk pengadaan elektronik, salah satu dasar baru manajemen persediaan, adalah mereka yang memperkuat posisi mereka sebagai bagian dari basis pemasok yang dihargai oleh perusahaan.

\section{B. TINJAUAN PUSTAKA}

\section{Pengadaan Elektronik}

Secara sederhana, pengadaan elektronik adalah solusi teknologi yang memfasilitasi pembelian perusahaan menggunakan Internet. Ia memiliki kekuatan untuk mengubah proses pembelian karena itu mencakup semua langkah yang diidentifikasi. Di sini pengadaan elektronik didefinisikan secara luas untuk memasukkan desain elektronik pada tahap pengembangan spesifikasi dari proses pembelian, diakhiri dengan upaya manajer persediaan untuk mengevaluasi dan menilai kinerja pemasok.

Indikasi yang paling jelas bahwa bisnis memahami, setidaknya secara intuitif, manfaat dari pengadaan elektronik ditemukan dalam proyeksi untuk pertumbuhan pembelian perusahaan yang diharapkan dilakukan di Internet. Sebagai contoh, Boston Consulting Group memperkirakan bahwa pembelian Internet bisnis-ke-bisnis akan mencapai \$ 2 triliun pada tahun 2003, naik dari \$ 92 miliar pada tahun 1998 (Whyte, 2000). Meskipun proyeksi bervariasi, mereka umumnya masih dalam kisaran ini, menunjukkan langkah tak terhindarkan menuju pembelian yang difasilitasi teknologi saat kita bergerak lebih dalam ke milenium baru.

Dapat dikatakan bahwa pengadaan elektronik bukanlah hal baru karena banyak perusahaan besar telah menerapkan teknologi pada proses pembelian selama beberapa dekade melalui pertukaran data elektronik atau Electronic Data Interchange (EDI). EDI memfasilitasi transfer transaksi antara dua mitra bisnis dengan mengintegrasikan database menggunakan format standar untuk pesanan pembelian dan elemen lain dalam transaksi pembelian. Menggunakan teknologi eksklusif yang disebut jaringan nilai tambah atau Value Added Network (VAN) untuk mengikat pembeli dan penjual bersama. 
EDI merupakan peningkatan atas pertukaran informasi berbasis kertas tradisional dengan memungkinkan pembeli untuk meneruskan informasi penting terkait pembelian langsung ke sistem pemasok, itu sangat mahal untuk diterapkan, sering kali sampai jutaan dolar. Oleh karena itu, biaya implementasi merupakan penghalang yang signifikan terhadap meluasnya penggunaan EDI sebagai fasilitator pengadaan elektronik berskala besar. Penggunaannya hanya terbatas pada perusahaan terbesar dan paling kuat di arena bisnis ke bisnis. Perkembangan terkini dalam EDI berbasis Internet yang meniadakan kebutuhan akan teknologi jaringan nilai tambah yang mahal akan membuka bentuk pengadaan elektronik tertua ini ke lebih banyak bisnis (Turban et al., 2000).

\section{Peran Pengadaan Elektronik dalam Proses Pembelian}

Seperti telah disebutkan, Pengadaan elektronik, penerapan teknologi Internet, meliputi setiap komponen utama dari proses pembelian. Dalam menetapkan persyaratan pembelian melalui proses pengembangan spesifikasi, konsepn desain elektronik telah muncul untuk membantu memfasilitasi keterlibatan pemasok awal. Pembeli dan penjual membagikan informasi secara real time untuk membangun spesifikasi yang menambah nilai pada produk yang dihasilkan. Komunikasi itu membantu meminimalkan kerumitan desain dan menghindari pembangunan dengan biaya yang tidak perlu ke dalam spesifikasi.

Pertukaran informasi realtime ini juga penting karena menyusutnya siklus hidup produk dan keunggulan kompetitif yang datang dari berkurangnya waktu ke pasar. Selain itu, komponen desain elektronik dari strategi pengadaan elektronik komprehensif membantu mengatasi efek silo yang datang dengan aktivitas desain yang berurutan. Desain elektronik memfasilitasi kolaborasi realtime di antara semua anggota internal dari tim pembelian lintas fungsi perusahaan, serta dengan pemasok, mencegah masalah setelah-fakta dalam produksi dan pembelian yang menciptakan inefisiensi dan tantangan kompetitif yang muncul dalam proses sekuensial tradisional (misalnya, desain produk yang tidak memfasilitasi kemudahan pembuatan atau desain yang membatasi pilihan pemasok yang mungkin). Contoh yang baik adalah Adaptec, penyedia transfer data dan perangkat keras komunikasi, yang telah secara substansial mengurangi waktu siklus desain-untuk-pengiriman dan menghemat \$10 juta dalam pengurangan inventaris dengan menggunakan proses desain kolaborasi berbasis web dengan pemasok utama di Hong Kong, Jepang, dan Taiwan (Anderson \& Lee, 2000).

Penggunaan Internet juga membantu perusahaan pembeli dalam semua tahap proses pemilihan pemasok, mulai dari prakualifikasi pemasok melalui pembangunan permintaan 
proposal komprehensif hingga pemilihan pemasok akhir. Penerapan teknologi Internet untuk langkah ini dalam proses pembelian dikenal sebagai e-sourcing. Misalnya, FreeMarkets, pelopor dalam sumber online melalui proses lelang terbalik, muncul sebagai pemimpin di bidang pengadaan elektronik ini.

FreeMarkets memiliki keahlian di banyak sektor industri yang memungkinkan mereka mengidentifikasi dan memenuhi syarat pemasok yang memenuhi persyaratan perusahaan pembeli (pelanggan Free Markets). Selain itu, Free Markets membantu organisasi pembeli mengembangkan permintaan multiparameter untuk proposal guna memastikan bahwa perusahaan pembeli mendapatkan pembelian biaya terendah. Pemilihan akhir sumber pasokan adalah hak prerogatif perusahaan pembeli. Keputusan itu menjadi lebih nyaman mengingat pekerjaan luas yang telah dilakukan dalam prakualifikasi dan permintaan proses pengembangan proposal yang dimediasi oleh teknologi $e$-sourcing.

Daya tarik solusi ini bagi perusahaan pembeli adalah dividen potensial yang sangat besar yang muncul ketika seseorang mempertimbangkan risiko versus imbalan. Solusi esourcing seperti yang disediakan oleh FreeMarkets sedikit membebani perusahaan pembeli. Potensi penghargaan yang datang dari mengidentifikasi pemasok terbaik dan berbiaya terendah adalah signifikan (Aberdeen Group, 2001).

Pendekatan lain, yang lebih eksklusif, untuk e-sourcing adalah Jaringan Proses Perdagangan General Electric atau General Electric's (GE's) Trading Process Network $(T P N)$. Di sini pembeli memposting permintaan untuk proposal di Internet untuk diakses oleh pemasok yang memenuhi syarat. Pemasok mengunduh permintaan dan mengirimkan penawaran secara elektronik. Pembeli mengevaluasi penawaran, bernegosiasi on line, dan memesan dengan penawar yang bertanggung jawab terendah. Sistem ini juga memfasilitasi pemrosesan transaksi dengan, misalnya, secara otomatis merekonsiliasi pesanan pembelian dengan faktur sebagai bagian dari proses pembayaran. Solusi seperti TPN berdampak pada pemilihan pemasok dan komponen perjanjian kontrak dari proses pembelian (Turban et al., 2000).

Memang, beberapa solusi pengadaan elektronik paling awal yang muncul sekitar 4 tahun yang lalu berfokus pada penetapan rutinitas pemesanan yang mengurangi biaya transaksi terkait dengan pembelian sumber daya yang beroperasi (biasanya pemeliharaan, perbaikan, dan persediaan operasi yang dikenal dengan istilah maintenance, repair and operating suplies (MRO). Salah satu pemimpin dalam komponen proses pembelian ini adalah Korporasi Ariba. Melalui teknologinya, pemrosesan trans-aksi MRO dari kontrak yang dibuat 
oleh pembeli dengan pemasok terpilih sepenuhnya otomatis dari permintaan hingga pembayaran. Pengguna yang berwenang diberikan akses ke sistem dari komputer desktop mereka. Permintaan dihasilkan melalui sistem, persetujuan dibuat secara elektronik, pesanan pembelian elektronik dibuat, dan pesanan dikirim langsung ke pemasok. Ini adalah solusi tanpa sentuhan untuk manajer persediaan.

Langkah terakhir dalam proses pembelian adalah evaluasi dan penilaian pemasok. Proses ini membutuhkan data kinerja yang luas dan akurat. Dalam sistem berbasis kertas tradisional, sulit untuk menangkap dan mengambil data untuk melakukan penilaian pemasok yang efektif dan efisien. Solusi pengadaan elektronik menyediakan kemampuan data penyimpanan bagi perusahaan tempat manajer persediaan dapat mencatat. Solusi pengadaan elektronik tidak hanya membantu untuk menangkap pembelian agregat dengan kode produk yang dibeli, tetapi juga membantu mencatat detail penting dalam catatan kinerja pemasok termasuk kinerja pengiriman dan tingkat kualitas.

Potensi luar biasa dari pengadaan elektronik telah mendorong penyedia perangkat lunak perencanaan sumber daya perusahaan atau enterprise resource planning (ERP) yang besar untuk menambahkan kemampuan pengadaan elektronik ke sistem mereka.

Sebagai contoh, Oracle Corporation telah mengembangkan solusi pengadaan lalu bayar yang mengotomatiskan siklus pengadaan lengkap. Fitur-fiturnya meliputi analisis pengeluaran, sumber strategis, kolaborasi pemasok, permintaan desktop, dan faktur dan pembayaran elektronik. Oracle memperkirakan bahwa solusi pengadaan ujung ke ujungnya dapat menghemat perusahaan 10-20\% dari total biaya pembelian (Figgins et al., 2001).

\section{Pengadaan Elektronik: Peringatan}

Meskipun teknologi pengadaan elektronik memiliki potensi signifikan untuk meningkatkan efektivitas dan efisiensi proses pembelian tetap ada peringatan yang harus di perhatikan. Bagi perusahaan untuk menyadari manfaat maksimum yang menciptakan nilai dari strategi pengadaan elektronik, proses pembelian harus dievaluasi untuk menentukan apakah perlu direkayasa ulang. Misalnya, pada tahap pengembangan spesifikasi, jika perusahaan memiliki sedikit sejarah kolaborasi lintas-fungsional dan keterlibatan pemasok awal, potensi kolaboratif komponen desain elektronik dari strategi pengadaan elektronik memiliki sedikit peluang untuk berhasil. Di sini, perlu ada transformasi dalam budaya perusahaan serta rekayasa ulang proses pengembangan spesifikasi. 
Atau, jika ada redudansi dalam proses persetujuan permintaan, redudansi itu perlu dihilangkan sebelum menerapkan solusi pengadaan elektronik. Seperti yang dikemukakan beberapa orang, inisiatif pengadaan elektronik yang sukses seringkali lebih disebabkan oleh aspek pengadaan daripada aspek elektronik (Gabbard, 2001). Teknologi ini adalah enabler. Itu tidak dapat memperbaiki proses yang cacat. Namun, ini adalah enabler yang kuat yang dapat menghasilkan nilai luar biasa bagi perusahaan dalam hal pendapatan yang lebih tinggi, pengurangan biaya, dan pemanfaatan aset yang lebih baik.

\section{Manfaat Pengadaan Elektronik}

Manajemen persediaan dan literatur pengadaan elektronik kaya dengan perkiraan manfaat dari pengadaan elektronik. Potensinya sangat besar sehingga pengadaan elektronik telah mengubah fungsi pembelian tradisional yang sebelumnya dipandang rendah menjadi senjata kompetitif. Manfaat yang GE sadari dari TPNnya adalah ilustratif.

Pengurangan biaya tenaga kerja dalam proses pembelian adalah salah satu alasan bahwa biaya transaksi turun begitu cepat dengan pengadaan elektronik. Dalam proses mengejar pembelian berbasis kertas yang padat karya, biaya transaksi dapat berkisar dari $\$ 70$ hingga $\$ 300$ per pesanan pembelian. GE melihat biaya-biaya itu turun $30 \%$. Perusahaan lain telah mengalami pengurangan lebih besar lagi, mencapai hampir 65\% (Whyte, 2000).

Pengurangan biaya material dalam kisaran 5\% hingga 20\% diwujudkan karena solusi pengadaan elektronik GE membantu perusahaan mencapai basis pemasok yang lebih luas dan mengidentifikasi hingga saat ini sumber pasokan yang tidak dikenal dan memenuhi syarat. Sistem ini juga memungkinkan departemen pembelian Perusahaan di seluruh dunia untuk berbagi informasi tentang pemasok terbaik mereka. Lainnya, manfaat yang kurang terukur, tetapi tidak kalah pentingnya, direalisasikan. Misalnya, terbebas dari upaya penciptaan nilai yang diperlukan untuk pemrosesan transaksi, departemen pembelian GE memperoleh 6 hingga 8 hari per bulan untuk bekerja pada inisiatif yang lebih strategis (Turban et al., 2000).

Secara umum, sistem pengadaan elektronik memungkinkan perusahaan untuk secara lebih efisien dan akurat menangkap dan mengagregasikan berapa banyak yang mereka belanjakan di seluruh perusahaan dalam berbagai bidang produk yang dibeli, memungkinkan perusahaan untuk membawa apa yang mungkin menjadi penguat daya beli yang signifikan ke pasar. Manfaat ini berkontribusi terhadap pengurangan biaya material 5\% hingga $20 \%$ yang 
telah dialami GE. Kisaran pengurangan biaya yang sama ini juga mengindikasikan apa yang dialami oleh pengguna pengadaan elektronik lainnya.

Mungkin yang paling berdampak adalah penelitian terbaru oleh Grup Aberdeen yang mengidentifikasi manfaat yang diperoleh perusahaan dari strategi e-sourcing. Selain pengurangan 5-20\% dalam biaya bahan, manfaat termasuk pengurangan sumber siklus sebesar 25-30\% dan waktu-ke-pasar sebesar 10-15\%. Memotong waktu siklus tersebut memiliki dampak signifikan pada potensi pendapatan yang dihasilkan perusahaan karena produk dapat dipasarkan lebih cepat, memungkinkan perusahaan memposisikan diri untuk merebut pangsa pasar dari posisi pasar pertama ke pasar. Secara keseluruhan, Grup Aberdeen memperkirakan bahwa penghematan biaya dari e-sourcing dapat menghemat perusahaanperusahaan AS sekitar \$ 690 miliar (Aberdeen Group, 2001).

Menurut beberapa perkiraan, persediaan rata-rata di perusahaan uji coba S\&P adalah \$ 500 juta atau sekitar 60 hari persediaan (Timme \& Williams-Timme, 2000). Meskipun berbeda dari perusahaan ke perusahaan, biaya untuk membawa inventaris itu berada dalam kisaran 20-40\%. Biaya-biaya tersebut termasuk biaya modal, pajak atas aset, keusangan dan kerugian, biaya penyimpanan, dan biaya asuransi. Efek pada biaya perusahaan dari mengurangi komponen inventaris dari basis aset perusahaan jelas.

Mungkin contoh terbaik adalah Dell Computer Corporation di mana meremehkan persediaan dan persediaan perdagangan untuk informasi adalah salah satu prinsip-prinsip operasi dasar perusahaan. Hasilnya adalah tingkat persediaan yang telah dipotong menjadi kurang dari 8 hari, atau sekitar $87 \%$ lebih rendah dari rata-rata perusahaan industri S \& P. Seperti yang dicatat Dell (1999), kaitan antara tren permintaan sehari-hari dan bahan yang masuk dari pemasok Anda sangat penting untuk kesuksesan Anda sehingga semakin pendek Anda dapat membuat tautan itu menjadi lebih baik dari Anda. Saat ini, kami memiliki akses ke teknologi yang sangat memudahkan informasi itu. Kami menyebut proses ini inventaris perdagangan untuk informasi.

\section{HASIL DAN PEMBAHASAN}

\section{Membuat Kasus Bisnis untuk Pengadaan Elektronik}

Membuat kasus bisnis untuk pengadaan elektronik mengharuskan manajer persediaan menunjukkan hubungan antara strategi pengadaan elektronik dan kinerja keuangan perusahaan. Literatur manajemen rantai pasokan menunjukkan bahwa banyak eksekutif tingkat perusahaan memiliki pandangan tradisional tentang manajemen rantai pasokan dan 
tidak sepenuhnya mengakui dampaknya pada semua bidang kinerja keuangan dan bahwa banyak profesional rantai pasokan tidak berbicara bahasa keuangan, karenanya gagal untuk mengartikulasikan nilai nyata dari solusi mereka di tingkat perusahaan (Timme \& WilliamTimme, 2000). Pengamatan itu bahkan lebih relevan jika seseorang berfokus pada manajemen pasokan pada ujung input dari rantai pasokan karena di sanalah sebagian besar pengeluaran perusahaan untuk kegiatan terkait rantai pasokan terjadi.

Belajar bahasa keuangan memerlukan manajer persediaan untuk menggunakan dan memahami konsep EVA. Kami sekarang beralih ke diskusi tentang EVA dan menyarankan bagaimana manajer persediaan dapat menggunakannya untuk membuat kasus bisnis untuk pengadaan elektronik.

\section{Nilai Tambah Ekonomis atau Economic Value Added (EVA)}

EVA, dikenal sebagai ukuran komprehensif penciptaan nilai, dikembangkan oleh perusahaan konsultan New York Stern Stewart and Company. Ini menyediakan lebih ukuran profitabilitas komprehensif daripada ukuran tradisional,karena itu menunjukkan seberapa baik perusahaan telah melakukan dalam kaitannya dengan jumlah modal yang digunakan (Prober, 2000). EVA diungkapkan sebagai berikut: Keuntungan yang dimiliki EVA dibandingkan dengan ukuran kinerja keuangan lainnya adalah bahwa ia menekankan dan mengisolasi kegiatan yang membantu mendorong penciptaan nilai. Kegiatan-kegiatan tersebut secara umum dapat dikategorikan sebagai pendapatan, biaya, dan aset). Kesadaran akan pendorong EVA utama meningkatkan apresiasi manajemen terhadap dampak inovasi, pengurangan biaya, peningkatan teknologi, dan upaya untuk mengurangi basis modal pada penciptaan nilai.

Tindakan yang dapat meningkatkan profitabilitas dan penciptaan nilai pada umumnya berada di bawah kendali perusahaan. Manajemen operasi yang lebih baik harus memiliki dampak besar pada pertumbuhan pendapatan, pengurangan biaya, dan perputaran aset. Namun, biaya unsur modal EVA berbeda. Ini sebagian besar ditentukan oleh kekuatan luar dan pada dasarnya diberikan dimana manajemen memiliki sedikit kontrol (Ray, 2001).

Oleh karena itu, penting untuk menyadari bahwa kunci untuk meningkatkan EVA adalah bagi perusahaan meningkatkan pengembalian modal melalui peningkatan produktivitas, umumnya, rasio nilai output yang dihasilkan dengan biaya input. Produktifitas dapat ditingkatkan dengan tiga cara: (1) dengan meningkatkan output sambil menjaga input tetap konstan; (2) dengan menghasilkan tingkat output yang sama sambil mengurangi biaya 
input; dan 3) idealnya, dengan meningkatkan produksi sekaligus mengurangi input, apa yang kemudian dikenal sebagai melakukan lebih banyak dengan biaya sedikit.

Apa pun jalan yang diambil untuk meningkatkan produktivitas, tidak ada yang lolos dari realisasi keterkaitan antara EVA dan produktivitas karena perusahaan akan menemukan bahwa nilai diciptakan ketika produktivitas mendorong pengembalian modal perusahaan melebihi biaya modal (Ray, 2001).

\section{Memasukkan Pengadaan Elektronik}

Alasan mengapa manajer persediaan perlu memahami EVA sebagai ukuran keuangan utama untuk membuat kasus bisnis untuk pengadaan elektronik adalah karena dampaknya yang luas pada unsur-unsur yang menciptakan nilai dari generasi pendapatan dan pengurangan biaya dan basis aset. Efek keseluruhan dari pengaruh positif terhadap pendapatan sambil mengurangi biaya input dan basis aset adalah untuk mendorong produktivitas perusahaan lebih tinggi.

a. Dampak pada Pendapatan

Seperti yang telah kita lihat, salah satu manfaat dari strategi pengadaan elektronik yang dikutip oleh Aberdeen Group adalah pengurangan siklus waktu-ke-pasar sebesar 1015\%. Desain elektronik dan hubungan dekat dengan pemasok dalam konsep integrasi virtual Dell adalah contoh dari solusi yang dimediasi teknologi dari strategi pengadaan elektronik yang dapat berdampak pada siklus tersebut dan, pada gilirannya, berdampak positif pada komponen pendapatan dari EVA.

Pengurangan signifikan dalam siklus waktu ke pasar adalah penting untuk peluncuran produk yang berhasil meningkatkan pendapatan. Namun, keunggulan ini tidak terbatas pada produk baru. Jika suatu perusahaan dapat membuat produk yang ada ke pasar lebih cepat ke pelanggan industri, kemampuan itu dapat berkontribusi pada tingkat persediaan yang lebih rendah untuk pelanggan, berdampak positif pada inisiatif penciptaan nilai pelanggan dengan memungkinkan pelanggan untuk beroperasi dengan basis aset yang lebih rendah . Kemampuan untuk membawa produk ke pasar lebih cepat dapat membantu perusahaan pemasok meningkatkan pendapatan melalui lebih banyak pangsa pasar yang lahir dari keunggulan kompetitif yang berasal dari pengurangan waktu ke pasar.

Mari kita asumsikan bahwa pengurangan $15 \%$ dalam waktu ke pasar meningkatkan pendapatan sebesar $1 \%$ untuk rata-rata perusahaan industri S \& P. Satu studi memperkirakan 
bahwa untuk produsen, dampaknya terhadap EVA (apa yang disebut penelitian sebagai keuntungan ekonomi) mendekati 100\% (Timme \& William-Timme, 2000).

b. Dampak pada Biaya

Dampak pengadaan elektronik terhadap biaya material dan transaksi sangat dramatis, seperti yang telah kita lihat. Pengurangan biaya material dapat berkisar dari 5\% hingga 20\% sedangkan biaya transaksi dapat dikurangi bahkan lebih dramatis $65 \%$. Efeknya pada EVA jelas. Pengurangan biaya tersebut turun secara langsung dan total ke garis bawah, memberikan dorongan signifikan pada elemen laba operasional EVA.

Dalam hal biaya material, orang mungkin berpendapat bahwa ada implikasi peningkatan pendapatan juga, sehingga pengurangan biaya material tidak hanya berdampak pada elemen biaya EVA tetapi juga elemen pendapatan. Anggaplah suatu perusahaan menghasilkan \$20 juta dalam pendapatan penjualan dan menghabiskan \$10 juta melalui fungsi manajemen persediaan pada bahan yang dibeli. Margin laba operasi perusahaan adalah $10 \%$. Ini mengadopsi strategi pengadaan elektronik yang mengurangi biaya material $5 \%$, di bagian bawah kisaran yang disarankan literature dapat diharapkan. Pengurangan biaya material \$ 500.000 yang dihasilkan langsung ke garis bawah perusahaan .

Mengingat skenario itu, perusahaan akan perlu menghasilkan tambahan $\$ 5$ juta dalam pendapatan penjualan (kenaikan 25\%) untuk merealisasikan peningkatan laba $\$ 500.000$ berdasarkan pada margin laba operasi $10 \%$. Rasio kenaikan pendapatan penjualan lima hingga satu ini terhadap pengurangan biaya material yang dibeli memiliki implikasi nyata untuk komponen pendapatan EVA karena penurunan komponen biaya memiliki dampak yang sama dengan peningkatan komponen pendapatan 25\%. Meskipun pertumbuhan pendapatan topline seringkali menjadi perhatian utama para eksekutif perusahaan, pertumbuhan itu tidak selalu mungkin terjadi dalam lingkungan ekonomi tanpa-pertumbuhan. Oleh karena itu, komponen biaya, yang secara substansial dipengaruhi oleh strategi pengadaan elektronik, dapat menjadi kunci untuk penciptaan nilai yang berkelanjutan dalam keadaan tersebut.

c. Dampaknya Terhadap Aset

Komponen inventaris dari basis aset perusahaan umumnya signifikan, sering kali mencakup sebanyak 30\% dari modal yang diinvestasikan perusahaan. Seperti yang kami sebutkan sebelumnya, rata-rata perusahaan industri S\&P memiliki persediaan sekitar $\$ 500$ juta, atau pasokan 60 hari. Itu setara dengan \$ 8 juta sehari untuk mendukung operasi perusahaan. Di sisi lain, perusahaan seperti Dell Computer, yang memperdagangkan informasi untuk inventaris sebagai bagian dari strategi pengadaan elektroniknya, memiliki 
persediaan kurang dari 8 hari. Demi perbandingan, mari kita asumsikan bahwa Dell memiliki 8 hari persediaan dan nilai persediaan setara dengan $\$ 8$ juta per hari untuk rata-rata perusahaan industri S\&P. Dell dapat mendukung operasinya dengan inventaris \$ 64 juta sebagai bagian dari basis asetnya.

Ini tidak hanya mengurangi basis aset EVA secara signifikan, semua hal lain sama, tetapi dampak pada komponen biaya EVA juga terpengaruh. Dengan asumsi faktor biaya pembawa $30 \%$, rata-rata perusahaan uji coba industri S\&P mengeluarkan biaya pengiriman \$ 150 juta versus sekitar \$ 19 juta yang akan dikeluarkan Dell. Seperti dalam kasus pengurangan biaya material, pengurangan biaya yang diciptakan oleh pengurangan komponen inventaris dari basis aset secara langsung meningkatkan profitabilitas perusahaan. Selain itu, sejumlah besar uang tunai tersedia untuk keperluan lain yang lebih produktif, seperti investasi dalam peralatan modal yang dibutuhkan atau untuk mendukung peningkatan yang berkesinambungan dalam sistem pengadaan elektronik.

Secara keseluruhan, strategi pengadaan elektronik yang efektif berdampak pada semua komponen EVA. Meskipun orang akan mengharapkan pengadaan elektronik berdampak pada komponen biaya dan basis aset, jelas bahwa strategi yang komprehensif juga dapat berdampak pada komponen pendapatan EVA.

\section{Keterbatasan EVA}

Seperti alat pengukuran lainnya, EVA dapat dimanipulasi oleh manajer untuk membuat situasi tampak lebih menguntungkan. Sebagai contoh, komponen biaya dapat dimanipulasi oleh meminimalkan pengeluaran diskresioner selama periode akuntansi. Program pelatihan karyawan adalah contohnya. Penghematan jelas meningkatkan komponen biaya, setidaknya dalam jangka pendek. Komponen pendapatan juga dapat dimanipulasi dengan mengirimkan pesanan yang lebih menguntungkan sebelum akhir periode akuntansi dan pesanan yang kurang menguntungkan setelah akhir periode, dengan ketentuan bahwa hubungan pelanggan tidak rusak tidak dapat diperbaiki dengan melakukan hal itu. Atau manajer dapat memanipulasi komponen basis aset dengan memutuskan untuk tidak mengganti aset yang sepenuhnya terdepresiasi. Kedua tindakan, seperti contoh pengurangan biaya, dapat berfungsi untuk meningkatkan EVA.

Juga telah diamati bahwa langkah-langkah keuangan agregat, hasil oriented seperti EVA yang diakumulasikan pada akhir periode akuntansi tidak membantu untuk mengidentifikasi akar penyebab ketidakefisienan operasional. Oleh karena itu, pengukuran 
ini menawarkan informasi berguna yang terbatas kepada orang-orang yang bertanggung jawab untuk mengelola proses bisnis (Brewer et al., 1999).

Pandangan berbeda diambil di sini. Diskusi sebelumnya menunjukkan bahwa unsur yang hilang dalam manajemen rantai pasokan adalah metode untuk mengukur total nilai ekonomi di seluruh rantai pasokan. EVA tidak hanya menyediakan ukuran keuangan yang komprehensif untuk melakukan hal itu tetapi, mengingat komponen-komponennya dalam menghasilkan pendapatan, biaya, dan aset, juga menyediakan kerangka kerja yang nyaman di mana perusahaan dapat mengidentifikasi kegiatan-kegiatan tersebut di setiap area komponen yang dapat ditangani untuk membantu meningkatkan kemampuan perusahaan untuk menciptakan nilai. Itu, pada kenyataannya, memberikan dasar di mana perbaikan proses bisnis dapat dibenarkan.

\section{Implikasi untuk Pemasaran Industri}

Potensi penciptaan nilai dari pengadaan elektronik memiliki implikasi signifikan bagi pemasar industri. Pada ujung pasokan atau input dari rantai pasokan perusahaan pembeli itulah pemasar industri berhadapan langsung dengan tuntutan yang berubah pada basis pemasok perusahaan pembeli. Pemasar industri perlu memahami manfaat penciptaan nilai yang mendorong pelanggan mereka atau pelanggan potensial untuk secara agresif mengeksploitasi keunggulan Internet dalam mengadopsi strategi pengadaan elektronik. Langkah ini jauh dari fokus transaksi yang lebih tradisional beli memiliki implikasi yang mendalam bagi pemasar industri.

Karena lebih banyak eksekutif puncak memandang manajemen persediaan sebagai kontributor utama strategi kompetitif, para pemasar industri yang berhasil membantu manajer pasokan mewujudkan strategi kompetitif perusahaan pembeli melalui inisiatif pengadaan elektronik akan menjadi anggota yang didambakan dari membeli basis pemasok perusahaan. Pengadaan elektronik adalah membuat bahkan lebih penting apa yang Theodore Leavitt mengidentifikasi sebagai saling ketergantungan, bentuk tertinggi dari pembeli-pemasok hubungan di mana pemasok bukanlah pengambil pesanan belaka, tetapi mitra bisnis sejati yang membantu membeli perusahaan membeli (Levitt, 1986).

Ada orang yang percaya bahwa strategi pengadaan elektronik akan membalikkan kecenderungan membangun hubungan pembeli-pemasok. Mereka menunjukkan efek korosif yang dimainkan oleh lelang terbalik, di mana perusahaan pembeli memberikan bisnis berdasarkan harga yang diterima dalam penawaran ke bawah yang dipicu oleh lelang 
terbalik. Namun, pemasar industri percobaan perlu memahami bahwa pendekatan lelang terbalik untuk pengadaan elektronik telah berkembang ke titik di mana tujuannya adalah untuk memberikan penghargaan pada bisnis dengan biaya rendah, bukan harga murah.

Ini mensyaratkan bahwa perusahaan pembeli menyiapkan permintaan terperinci untuk proposal yang mencakup semua komponen penting dari pembelian, langkah awal yang penting dalam membangun hubungan baik pembeli-pemasok karena mengharuskan pembeli melakukan sejumlah besar perencanaan lanjutan. Semakin banyak, manajer persediaan yang canggih akan melihat hasil dari lelang terbalik sebagai langkah awal untuk membangun hubungan jangka panjang dengan pemasok (Presutti Jr \& Zuffoletti, 2002).

\section{KESIMPULAN}

Para eksekutif puncak berwawasan ke depan sangat ingin memanfaatkan kekuatan teknologi untuk meningkatkan posisi kompetitif perusahaan mereka. Pada saat yang sama, mereka menjadi semakin sadar akan kekuatan manajemen pasokan yang efektif karena pada bagian akhir dari rantai pasokan itulah $50 \%$ atau lebih dari pendapatan penjualan perusahaan dihabiskan untuk membantu mendukung operasi perusahaan.

Ini adalah kebersamaan dari dua kekuatan yang telah membawa tahap pusat pengadaan elektronik sebagai pengembangan paling signifikan dalam manajemen pasokan dalam beberapa tahun terakhir. Dampak teknologi Internet pada apa yang secara tradisional disebut proses pembelian telah menyebar, dimulai dengan bagaimana pemasok dan anggota internal tim pembelian perusahaan terlibat dengan proses pengembangan spesifikasi hingga pengumpulan data sistematis untuk sepenuhnya mengumpulkan dan secara obyektif mengevaluasi kinerja pemasok.

Mengingat potensi yang dimiliki oleh pengadaan elektronik untuk memberikan kontribusi yang signifikan terhadap strategi perusahaan secara keseluruhan, kekuasaan ini terletak pada manajer persediaan untuk dapat membuat kasus bisnis untuk adopsi. Manajer persediaan perlu nyaman berbicara bahasa manajemen puncak dengan menggunakan langkah-langkah keuangan untuk membuat kasus mereka. Mungkin ukuran paling komprehensif yang dapat mereka gunakan adalah EVA. Komponen EVA dari pendapatan, biaya, dan aset semuanya dapat dipengaruhi oleh strategi pengadaan elektronik. Menerapkan EVA juga akan memungkinkan manajer persediaan untuk berkontribusi pada unsur yang hilang dalam perpindahan keseluruhan ke manajemen rantai pasokan yang lebih efektif metode untuk mengukur penciptaan nilai di seluruh rantai pasokan. 
Karena pemasar industri berinteraksi dengan rantai pasokan perusahaan pembelian pada ujung input rantai, implikasi kemunculan pengadaan elektronik jelas. Semakin banyak, manajer suplai akan mencari pemasok yang dapat membantu mereka menciptakan nilai bagi perusahaan mereka melalui pengadaan elektronik yang efektif.

\section{REFERENSI}

Aberdeen Group. (2001). E-sourcing: Negotiating Value in a Volatile Economy-An Executive White Paper. Boston (MA).

Anderson, D. L., \& Lee, H. L. (2000). The internet-enabled supply chain: From the "first click" to the "last mile". Achieving supply chain excellence through technology, 2(4), $1-7$.

Brewer, P. C., Chandra, G., \& Hock, C. A. (1999). Economic value added (EVA): Its uses and limitations. SAM Advanced Management Journal, 64(2), 4-11.

Dell, M. (1999). Direct from dell. New York: Harper-Collins.

Dobler, D. W, \& Burt D. N. (1996). Purchasing and supply management. New York: McGraw-Hill.

Figgins, L., Glovier, D., Griffith, M., Sculimbrene, D., \& South, B. (2001). Unpub-lished graduate research paper on Oracle vs. SAP in E-procurement. Duquesne University, John F. Donahue Graduate School of Business: Pittsburg, PA, USA.

Gabbard, E. G. (2001). Establishing successful e-procurement. Purchasing Today, 12(8), 10Handfield, R. B., \& Nichols Jr, E. L. (1999). Introduction to Supply Chain Management. Upper Saddle River, NJ: Prentice-Hall.

Levitt, T. (1986). The Marketing Imagination. New York: The Free Press.

Nelson, D., Moody, P., Stegner, J. (2002). The Purchasing Machine. New York: The Free Press.

Presutti Jr, W. D., \& Zuffoletti, J. (2002). The buyer-seller relationship and the impact of reverse auctions. E-purchasing plus. Goshen, NY: JGC Enterprises.

Prober, L. M. (2000). EVA: A better financial reporting tool. Pennsylvania CPA Journal, 71(3), 27-27.

Ray, R. (2001). Economic Value Added: Theory, Evidence, A Missing Link. Review of Business, 22.

Timme, S. G., \& Williams-Timme, C. (2000). The financial-SCM connection. Supply Chain Management Review, 4(2), 33-40.

Turban, E., Lee, J., King, D., Chung, M. H. (2000). Electronic commerce. Upper Saddle River, NJ: Prentice-Hall.

Whyte, C. K. (2000). E-procurement: the new competitive weapon. Purch Today 25. 